\title{
Towards Silviculture Guidelines to Produce Large-Sized Silver Birch (Betula pendula Roth) Logs in Western Europe
}

\author{
Héloïse Dubois *, Hugues Claessens and Gauthier Ligot
}

check for updates

Citation: Dubois, H.; Claessens, H.; Ligot, G. Towards Silviculture Guidelines to Produce Large-Sized Silver Birch (Betula pendula Roth) Logs in Western Europe. Forests 2021, 12, 599. https://doi.org/10.3390/ f12050599

Academic Editor: Matthew B. Russell

Received: 16 April 2021

Accepted: 8 May 2021

Published: 11 May 2021

Publisher's Note: MDPI stays neutral with regard to jurisdictional claims in published maps and institutional affiliations.

Copyright: (c) 2021 by the authors. Licensee MDPI, Basel, Switzerland. This article is an open access article distributed under the terms and conditions of the Creative Commons Attribution (CC BY) license (https:/ / creativecommons.org/licenses/by/ $4.0 /)$.
TERRA Teaching and Research Centre (Forest Is Life), Gembloux Agro-Bio Tech, University of Liege, Passage des Déportés 2, BE-5030 Gembloux, Belgium; hugues.claessens@uliege.be (H.C.); gligot@uliege.be (G.L.)

* Correspondence: heloise.dubois@alumni.uliege.be; Tel.: +32-81-62-23-81

\begin{abstract}
Forest health problems arising from climate change, pests and pathogens are a threat to the main timber tree species. As a result, silver birch (Betula pendula Roth) has become a precious asset for meeting oncoming forestry challenges in western Europe. However, silviculture guidelines to produce high-value birch logs in this region are lacking. Producing large-sized birch trunks requires crown release, i.e., removing crown competitors around selected target trees. These interventions are currently seldom carried out or else too late when the growth potential of the trees has already diminished. This study set out to ascertain the diameter at breast height ( $\mathrm{dbh}$ ) that could be reached by crown-released birch, determine dbh-associated crown diameters, and further characterize the gain obtained from early crown release on birch dbh growth. We measured 704 birch trees that had undergone crown release in 38 naturally regenerated pure birch stands in southern Belgium and in northeastern France. We then evaluated the variation in stem and crown diameter, and analyzed increments in response to the earliness of the interventions in three subsamples, also compared with control target birch. We found that trees with a dbh of $50 \mathrm{~cm}$ could be grown within 60 years. Based on crown diameter, to produce 40,50 and $60 \mathrm{~cm}$ dbh trunk, the distance required between target birch trees at the end of the rotation was around 8,10 and $12 \mathrm{~m}$. With no intervention and in ordinary dense birch regenerations, the dbh increment was found to decline once the stand reached age 4-7 years. Starting crown release in stands aged $4-5$ years can double the dbh increment of target trees and provide a continual gain that may last up to 20 years. When birch crowns are released after 9-12 years, it may already be too late for them to recover their best growth rate. Our contribution should help complete emerging guidelines in support of birch silviculture development.
\end{abstract}

Keywords: diameter at breast height growth; crown release; crop tree silviculture; crown development

\section{Introduction}

One of the key recommendations for adapting European forests to global change is to diversify tree species composition [1-4]. Silver birch (Betula pendula Roth), which has mostly been neglected until now in western European forestry, is one candidate. According to FAO reports, the birch resource (of both Betula pendula Roth and Betula pubescens Ehrh.) in this region comprises 1-15\% of all hardwood standing volume, depending on the country, and is sharply increasing [5]. Moreover, socioeconomic and climatic context is favoring the expansion [6] of this colonizer, which regenerates profusely in forests after disturbances such as clearcuts, storm damage and disease [7-10]. Birch thus offers an attractive option to help meet present and future challenges of forest management $[6,9,10]$.

In western Europe, birch is set aside because it colonizes young forest plantations, acting as a strong competitor of the planted trees. Most exploited birch timber is also poorly sized and of low quality (wrong stem shape, rot and knots) [6]. Without proper silvicultural operations, birch rarely achieves the qualities needed for the high-value timber market $[6,9,10]$. The wood industry has therefore been unable to make gainful use of the 
birch resource and so forest owners have neglected this species. However, both the wood industry and forest owners have lately been taking a renewed interest in birch timber now that some other current abundant commercial tree species, e.g., Norway spruce (Picea abies (L.) Karst) or beech (Fagus sylvatica L.), are threatened with decline owing to climate change and forest health issues [6,11,12].

Specific silvicultural guidelines to produce high-value birch timber in western Europe are lacking $[6,9,13]$. These should be based on the life traits of birch, a light-demanding pioneer species with an early and rapid but unsustained height growth, sharply decreasing around age 30-40 years [9,10,14-16]. Following Hein et al. [9], in south-west Germany, diameter at breast height $(\mathrm{dbh})$ growth is potentially high during the first 10-20 years. However, in natural regeneration, where birch tends to form very dense pure stands [17,18], strongly restricting crown development e.g., [10,18-20], dbh increment of dominant birches is maximal once the stand is 5-7 years old and then sharply decreases [17,21,22]. According to Cameron [23], "the longer that a birch stand remains unmanaged the less is its response to thinning". This situation also leads to thin trunks that are sensitive to snow damage [24]. Vanhellemont et al. [13] found that birch dbh increment was closely correlated with tree age and crown size and that trees never recovered a high growth rate if crown expansion was hindered during youth. However, to mitigate the risk of developing wood rot or heart discoloration due to senescence, the rotation should be less than 60 years to produce rot-free logs of silver birch $[9,10]$.

In the current wood-industry context in western Europe, forest managers need to produce large-sized straight birch logs free from knots, scars, cracks, and decay, as feedstock for sawmills or slicing and rotary cutting mills $[6,9,25,26]$. Owing to the rapid early growth of birch but its low resistance to competition, and the deterioration of the wood when aging or wounded $[8,27,28]$, a promising method of birch silviculture is to promote dbh growth of a limited number of selected birches, called target trees, and artificially prune their stems $[6,9,28]$. This method can be well-controlled through crop tree silviculture [26], based on local thinning, called crown release, whereby all the crown competitors around the target trees are removed, keeping alive the branches at the base of the crown for maximum growth potential. With this treatment, selected birch can grow fast, reach large size before wood depreciation, and produce timber with good mechanical characteristics [29].

The effect of this silvicultural treatment on the dbh growth of target birches has been scantly studied e.g., $[9,13]$. In western European conditions, very few birch stands have undergone crown release. Silvicultural recommendations are diverse and scattered across contrasting ecological conditions. In Great Britain, Cameron [23] suggested starting thinning at a mean stand height of 8-10 $\mathrm{m}$ when the trees are 8-10 years old. In Spain, it was recommended to start the thinning when the trees are 2-3 years old [30]. In Germany, Hein et al. [9] suggested that the first thinning should not take place after 25 years and Wilhelm and Rieger [26] recommended starting crown release at age 12-15 years.

This study set out to further describe birch dbh and crown development under crop tree silviculture for the purpose of designing efficient silvicultural guidelines to produce large-sized birch timber. To this end, we set up experimental plots and measured target birch trees that had undergone crown release in birch pure natural regeneration in southern Belgium and in northeastern France. We particularly aimed to:

1. Identify the general dbh growth response to crown release to predict the trunk dimensions that could be reached at age 60 years (maximum age to limit the risk of wood degradation),

2. Quantify and compare the gain in dbh increment of different crown release scenarios starting very early (at age 1-5 years) or late (at age 9-19 years) with a scenario without silviculture (control),

3. Fit an allometric relationship between dbh and crown diameter to design suitable crop birch silviculture scenarios (e.g., minimum distance between target trees or number of target trees per hectare according to the dbh objective). 


\section{Materials and Methods}

\subsection{Study Sites, Plot and Tree Selection}

The study sites were located in southern Belgium and in northeastern France (Figure 1), in Europe's temperate oceanic bioclimatic zone [1]. To take as many opportunities as possible, we gathered a heterogeneous dataset of target birch trees that had undergone crop tree silviculture and had originated from pure naturally regenerated birch stands. The target birch trees were selected based on their own vigor and dominance status, their stem quality (straightness, no forks, large branches or wounds) and their distance from other target birch trees. We analyzed the growth of 704 crown-released target birch trees (number of trees at the last measurement) and 110 control target birch trees aged 4-66 years located in 38 stands. Four different datasets were gathered for the needs of this study (Table 1):

- $\quad$ The first dataset contained 87 target birch trees aged 8-41 years. They were sampled in five experimental plots. Crown release and measurements were carried out for 12 to 19 years (sites 1 to 5 ).

- The second one contained 142 target birch trees in three experimental plots (sites 6 to 8). The first crown release was carried out at different ages ranging from 1 to 19 years. These were compared with 110 target birch trees in control plots that were identified but never crown-released.

- $\quad$ The third one contained 429 target birch trees aged 7-42 years. They were sampled in 15 plots. Crown release was performed by the local forest manager (sites 9 to 23).

- The fourth one contained 46 forest birch trees that had grown almost free of competition. Given their crown development and the height of the first living branch, they were considered as target birch even though they had not formally undergone crop tree silviculture. These trees were sampled in 15 sites and were aged 27-66 years (sites 24 to 38$)$.

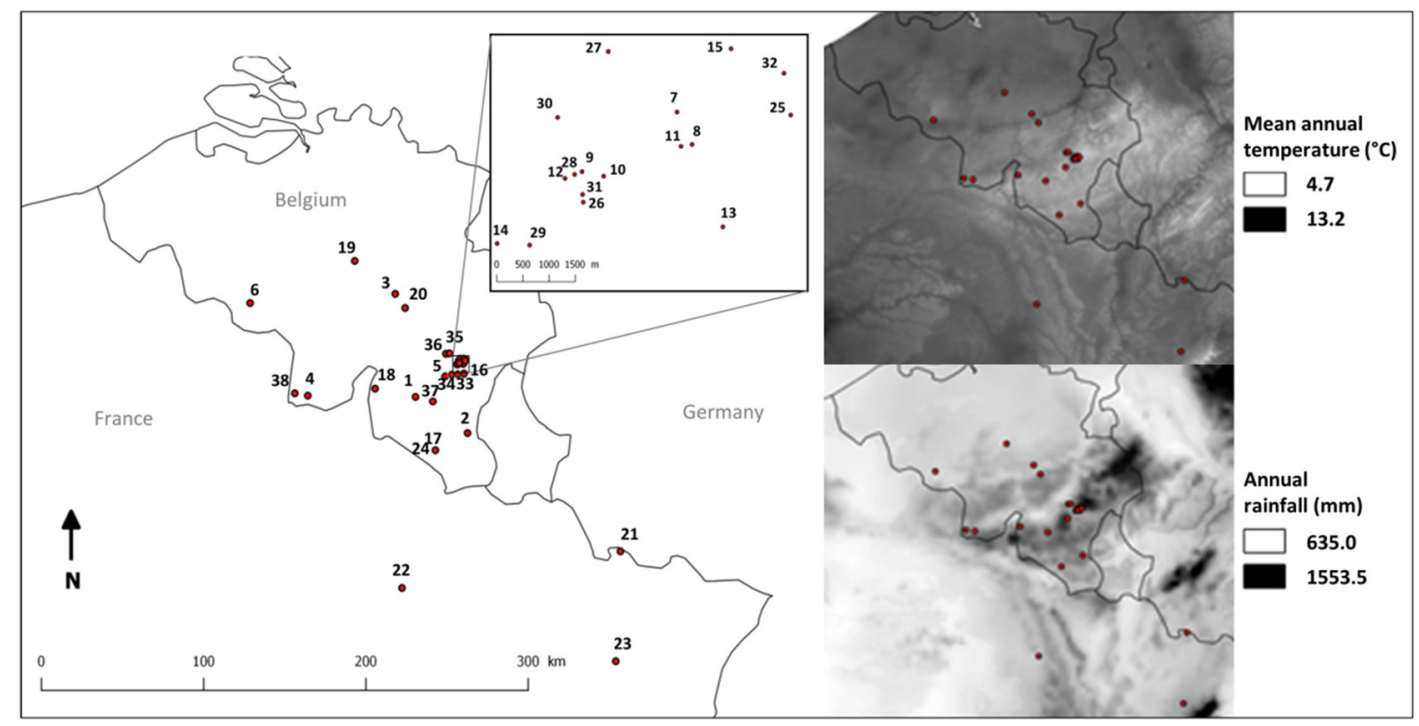

Figure 1. Site location and climatic gradient (mean annual temperature an annual rainfall) in the study area.

The study sites were mostly representative of fresh or slightly dry soils with poor or medium nutrient status (Figure 2), the most frequent soils in which birch trees grew well in the study area. The plots were located at 77-549 m (mean: $354 \mathrm{~m}$ ) above sea level (Table 1). 
Table 1. Description of the monitoring period, silvicultural treatment (age of first crown release) and ecological conditions of each plot. For each plot is also given the final number of monitored target trees together with the mean, minimum and maximum dbh at the last measurement. In cases of heart decay, the number of tree rings could not be counted and so tree age could not be estimated.

\begin{tabular}{|c|c|c|c|c|c|c|c|c|c|c|}
\hline & Site & $\begin{array}{l}\text { Age of } \\
\text { First } \\
\text { Crown } \\
\text { Release }\end{array}$ & $\begin{array}{l}\text { Measure- } \\
\text { ment } \\
\text { Period } \\
\text { (Years) }\end{array}$ & $\begin{array}{l}\text { Age at the } \\
\text { Last Mea- } \\
\text { surement }\end{array}$ & $\begin{array}{c}\text { Final } \\
\text { Number } \\
\text { of Target } \\
\text { Birches }\end{array}$ & Mean & (Min-Max) & $\begin{array}{c}\text { Annual } \\
\text { Rainfall } \\
\text { (mm) }\end{array}$ & $\begin{array}{c}\text { Mean } \\
\text { Annual } \\
\text { Temperature } \\
\left({ }^{\circ} \mathrm{C}\right)\end{array}$ & $\begin{array}{l}\text { Elevation } \\
\text { (m Above } \\
\text { Sea Level) }\end{array}$ \\
\hline \multirow{7}{*}{ 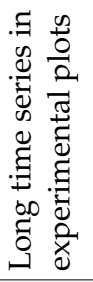 } & 1 & 10 & 19 & 29 & 12 & 24.7 & $(21.3-28.6)$ & 1109 & 7.7 & 453 \\
\hline & \multirow[b]{2}{*}{2} & 11 & 18 & 29 & 12 & 19.5 & (16.9-25.8) & \multirow[b]{2}{*}{1107} & & \\
\hline & & 8 & 18 & 26 & 17 & 17.6 & $(13.7-21.0)$ & & 7.7 & 450 \\
\hline & \multirow{2}{*}{3} & 12 & 18 & 30 & 16 & 25.7 & $(16.2-32.5)$ & \multirow{2}{*}{923} & \multirow{2}{*}{9.1} & \multirow{2}{*}{204} \\
\hline & & 20 & 18 & 30 & 3 & 24.0 & $(22.0-26.1)$ & & & \\
\hline & 4 & 23 & 18 & 41 & 22 & 25.7 & $(19.1-32.1)$ & 1073 & 8.8 & 303 \\
\hline & 5 & 25 & 14 & 39 & 5 & 25.6 & $(22.0-29.3)$ & 1236 & 7.7 & 458 \\
\hline \multirow{9}{*}{ 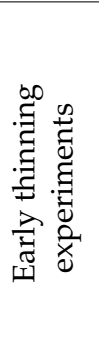 } & \multirow{4}{*}{6} & 1 & 20 & 32 & 10 & 34.6 & $(30.6-40.4)$ & \multirow{4}{*}{787} & \multirow{4}{*}{9.7} & \multirow{4}{*}{77} \\
\hline & & 12 & 20 & 32 & 6 & 25.9 & $(22.6-29.6)$ & & & \\
\hline & & 19 & 20 & 32 & 8 & 22.9 & $(15.9-29.6)$ & & & \\
\hline & & - & 11 & 32 & 7 & 21.3 & $(17.8-24.8)$ & & & \\
\hline & \multirow{3}{*}{7} & 4 & 7 & 10 & 49 & 9.1 & $(6.5-14.3)$ & \multirow{3}{*}{1276} & \multirow{3}{*}{7.5} & \multirow{3}{*}{516} \\
\hline & & - & 7 & 10 & 61 & 7.9 & $(4.1-13.0)$ & & & \\
\hline & & 5 & 7 & 11 & 36 & 8.6 & $(4.3-13.6)$ & & & \\
\hline & \multirow[t]{2}{*}{8} & 9 & 7 & 11 & 33 & 7.7 & $(4.5-11.6)$ & \multirow[t]{2}{*}{1276} & \multirow[t]{2}{*}{7.7} & 470 \\
\hline & & - & 7 & 11 & 42 & 6.8 & $(3.5-12.1)$ & & & \\
\hline & & 11 & 15 & 25 & 18 & 24.0 & $(15.9-29.9)$ & & & \\
\hline & 9 & 11 & 10 & 20 & 24 & 20.2 & (15.6-28.3) & 1022 & 8.7 & 327 \\
\hline & 10 & 8 & 6 & 13 & 68 & 12.2 & $(8.1-19.4)$ & 1089 & 8.6 & 360 \\
\hline ర్ & 11 & 14 & 2 & 16 & 20 & 13.6 & $(6.7-21.8)$ & 1276 & 7.8 & 447 \\
\hline & 12 & 17 & 4 & 21 & 11 & 18.3 & $(14.2-26.8)$ & 1022 & 8.8 & 321 \\
\hline$\Xi$ & 13 & 23 & 2 & 25 & 15 & 23.0 & $(18.0-29.0)$ & 1072 & 8.1 & 395 \\
\hline 馬 & 14 & 1 & 1 & 17 & 2 & 22.3 & $(21.7-22.8)$ & 952 & 8.6 & 362 \\
\hline 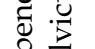 & 15 & 17 & 4 & 21 & 4 & 20.1 & $(15.3-25.5)$ & 1375 & 7 & 549 \\
\hline$\frac{0}{0}=$ & 16 & 30 & 2 & 37 & 8 & 28.6 & $(22.8-35.0)$ & 958 & 7.7 & 368 \\
\hline ర్ల & 17 & 4 & 1 & 10 & 28 & 16.0 & $(12.4-23.6)$ & 954 & 8.2 & 360 \\
\hline$\frac{\pi}{\infty}$ & 18 & 10 & 7 & 19 & 73 & 18.6 & (12.4-27.7) & 1053 & 8.4 & 319 \\
\hline$\Xi \widetilde{0}$ & 19 & 1 & 3 & 42 & 20 & 39.9 & $(32.5-56.7)$ & 789 & 9.8 & 111 \\
\hline & 20 & 7 & 4 & 11 & 38 & 12.9 & $(8.9-19.1)$ & 975 & 8.9 & 241 \\
\hline & 21 & 17 & 8 & 25 & 38 & 23.1 & $(19.3-33.5)$ & 864 & 9.9 & 250 \\
\hline & 22 & 9 & 6 & 15 & 31 & 16.5 & $(12.7-23.9)$ & 843 & 9.8 & 250 \\
\hline & 23 & 15 & 8 & 23 & 31 & 24.1 & $(19.7-30.4)$ & 973 & 9.6 & 350 \\
\hline & 24 & - & 1 & / & 9 & 44.8 & $(33.7-56.7)$ & 949 & 8.2 & 360 \\
\hline & 25 & - & 2 & / & 4 & 40.1 & $(36.6-44.6)$ & 1337 & 7.2 & 506 \\
\hline$\stackrel{2}{\beth}$ & 26 & - & 2 & 61 & 1 & & 58.6 & 1022 & 8.7 & 358 \\
\hline 3 & 27 & - & 5 & / & 2 & 29.2 & $(29.0-29.3)$ & 1276 & 7.7 & 438 \\
\hline 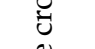 & 28 & - & 3 & 48 & 1 & & 50.9 & 1022 & 8.7 & 327 \\
\hline 8 & 29 & - & 1 & 66 & 2 & 53.1 & $(51.1-55.1)$ & 952 & 9.2 & 256 \\
\hline పี & 30 & - & 4 & 63 & 2 & 46.0 & $(45.2-46.8)$ & 1106 & 7.9 & 437 \\
\hline$\Phi$ & 31 & - & 2 & 58 & 1 & & 40.7 & 1022 & 8.6 & 349 \\
\hline 3 & 32 & - & 2 & 49 & 1 & & 56.3 & 1402 & 7.3 & 505 \\
\hline 돈 & 33 & - & 2 & / & 1 & & 47.5 & 1016 & 8.1 & 419 \\
\hline 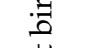 & 34 & - & 2 & 51 & 8 & 39.3 & $(32.3-43.9)$ & 995 & 7.5 & 392 \\
\hline 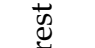 & 35 & - & 0 & / & 2 & 43.5 & $(34.7-52.5)$ & 928 & 9.2 & 194 \\
\hline కัّ & 36 & - & 2 & 29 & 1 & & 47.1 & 926 & 8.9 & 256 \\
\hline & 37 & - & 0 & / & 1 & & 30.5 & 1129 & 8.2 & 448 \\
\hline & 38 & - & 0 & 1 & 10 & 47.4 & $(36.6-58.6)$ & 1017 & 8.9 & 276 \\
\hline & & & Total & & 814 & & & & & \\
\hline
\end{tabular}




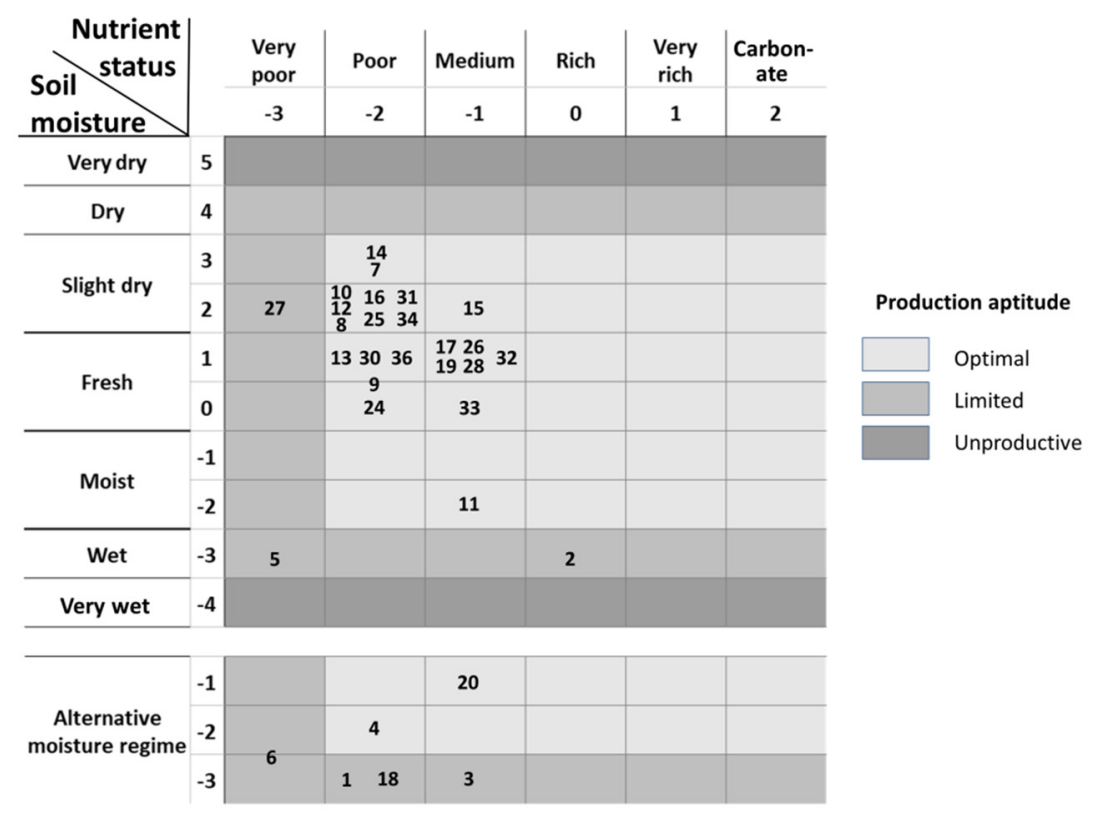

Figure 2. Soil nutrient and moisture levels of the sampled plots (site number) and birch production aptitude (cell color) based on the Afforestation Guide of Wallonia [31].

The first crown release occurred in the sampled stand when the birch trees were $1-$ 30 years old (mean: 10 years) (Table 2). Crown releases were repeated as often as necessary by the crown-touching method [32], i.e., all the competitive trees that touched the target birch crown were felled. Neighboring competitors that could touch the target birch with movements caused by the wind were also felled to prevent damage due to birch crown collisions [33]. This subjective method was preferred to the cutting-distance method that systematically removes neighboring trees within a set distance from the target tree [32]. The crown-touching method was found to be more efficient as it takes into account all particular cases such as bending trees [32].

Table 2. Description of the studied crown released target birch trees at their last measurement (Only one measure per tree): Some target birch were harvested earlier than the others within their plot to prevent crown contact between target trees. They had been predesignated as extra target birch for a further designation or because of underestimation of crown development.

\begin{tabular}{|c|c|c|c|c|}
\hline $\begin{array}{l}\text { Last Measure of Each Target Birch } \\
(n=996)\end{array}$ & Mean & Min & Median (Q1-Q2) & Max \\
\hline $\mathrm{dbh}(\mathrm{cm})$ & 18.6 & 2.4 & $16.2(10.6-23.3)$ & 58.6 \\
\hline Height (m) & 17.4 & 3.4 & $18.2(12.8-21.3)$ & 33.6 \\
\hline Crown proportion (vertical length of the living crown relative to the total tree height) & 0.60 & 0.29 & $0.59(0.52-0.66)$ & 0.91 \\
\hline Age (years) & 20.4 & 5 & $19(12-25)$ & 66 \\
\hline Age at first crown release (years) & 10.4 & 1 & $8(8-14)$ & 30 \\
\hline
\end{tabular}

\subsubsection{Tree Measurements}

For each target birch, we measured once or periodically: girth at breast height with a tape, tree height and the height of the base of the living crown with a Vertex IV hypsometer, and eight crown radii (i.e., the distance between trunk center and the vertical projection of the branch tip in the eight cardinal and intercardinal directions) with a compass, a Vertex IV hypsometer, and a Suunto clinometer to ensure vertically upward sighting. 
Tree age was determined by counting the number of annual tree rings on wood discs taken at the stem base of minimum two dominant birch trees per stand. The rings were accurately counted with WinDENDRO software after sanding the wood discs to grain 320 and scanning at very high resolution (with an Epson Expression 10000 XL scanner). The age of some trees could not be estimated because the heart of the disc was rotten.

\subsubsection{Statistical Analyses}

Firstly, we used the whole dataset, except for the control target birch and the birch that could not be aged, to graphically analyze patterns of dbh evolution by individual, plot, site, or as a whole. This procedure enabled us to discuss our results considering the specific features of the different datasets and sites.

Secondly, we used the whole dataset, except for the control target birch trees, to model the allometry between tree crown diameter and dbh with a linear mixed-effects model (Equation (1)) taking into account that the observations were grouped by plot. Crown diameter was chosen as the response variable because measuring crown diameter is subject to greater error than measuring $\mathrm{dbh}$. In addition, this choice was also justified by the fact that, generally, crown diameter is unknown and must be estimated while tree dbh is readily measured or available. The model was fitted with only one measure per tree. We chose the last measured crown diameter to use data from trees that had grown for as long as possible under crown release. Model fit was evaluated by computing the root mean square error (RMSE).

$$
C_{i j}=\beta_{0}+\beta_{1} \mathrm{dbh}_{i j}+\alpha_{j}+\varepsilon_{i j}
$$

where $C_{i j}$ is the crown diameter of individual $i(\mathrm{~m})$ in plot $j, \beta_{0}$ and $\beta_{1}$ are fixed-effects parameters, $\mathrm{dbh}_{i j}$ is the diameter at breast height of individual $i(\mathrm{~cm}), \alpha_{j}$ is the random between-plot effect, and $\varepsilon_{i j}$ is the residual within-plot variation.

Thirdly, the effect of the earliness of crown release on dbh increment was analyzed with the data from sites 6,7 and 8, including the control target birch trees. ANOVA and Tukey tests were carried out to test the significance of the effect of each treatment. Statistical assumptions were verified. As treatment varied across sites, and each had its own natural regeneration density, these analyses were repeated for each site.

Analyses were performed with R software (version 3.4.2) [34] with packages dplyr [35], nlme [36] and ggplot2 [37].

\section{Results}

\subsection{Descriptive Statistics of Tree Increment}

Taking all the measurements of each crown-released tree, the ages of the target birch ranged between 4 and 61 years and their dbh ranged between 1.2 and $58.6 \mathrm{~cm}$ (Figure 3) with an average of $18.6 \mathrm{~cm}$ considering their last measure. Most observations concerned birch younger than 35 years (Figure 3 ) as the mean age at the last measurement was 20 years (Table 2). The mean age at the first crown release was 10.4 years (Table 2), but the experiments with very young birch (e.g., sites 7 and 8) contained large numbers of individuals.

The dataset showed a wide dispersion of dbh growth trajectories. For example, at around age 40 years, target birch dbh ranged between $18 \mathrm{~cm}$ and $56 \mathrm{~cm}$ (Figure 3).

Our results showed that the best growing target birch could reach $40 \mathrm{~cm}$ in $\mathrm{dbh}$ at age 30-40 years or $50 \mathrm{~cm}$ in dbh at age 40-60 years. Nevertheless, some target birch trees failed to reach $10 \mathrm{~cm}$ in $\mathrm{dbh}$ at age 20 years. 


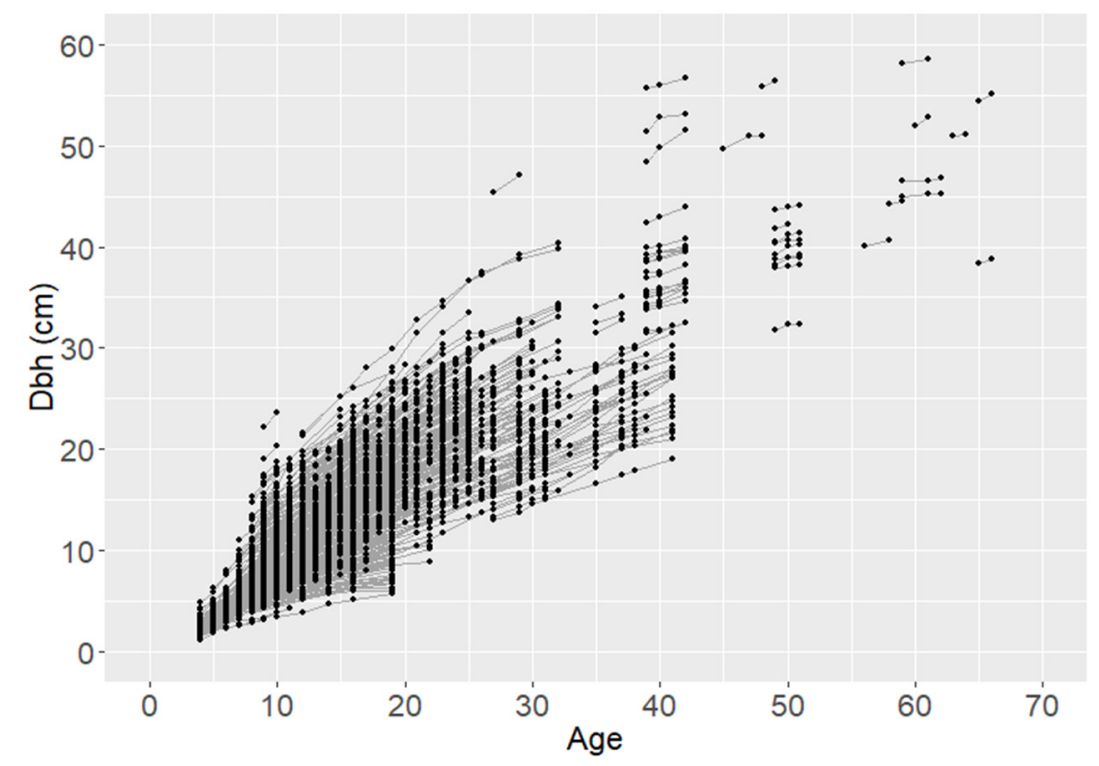

Figure 3. Temporal variation of target tree $\mathrm{dbh}$ (trees from the control plots not included). The gray lines connect the successive measurements of a tree.

\subsection{Crown Development}

A strong linear relationship was found between crown diameter and dbh (Figure 4 and Table 3). The root mean square error was 0.61 . The data distribution is quite close to the regression line. For a given dbh, most of the crown diameters do not deviate by more than $1 \mathrm{~m}$ from the prediction, and the maximum range is about $2 \mathrm{~m}$ except for a few outliers (Figure 4).

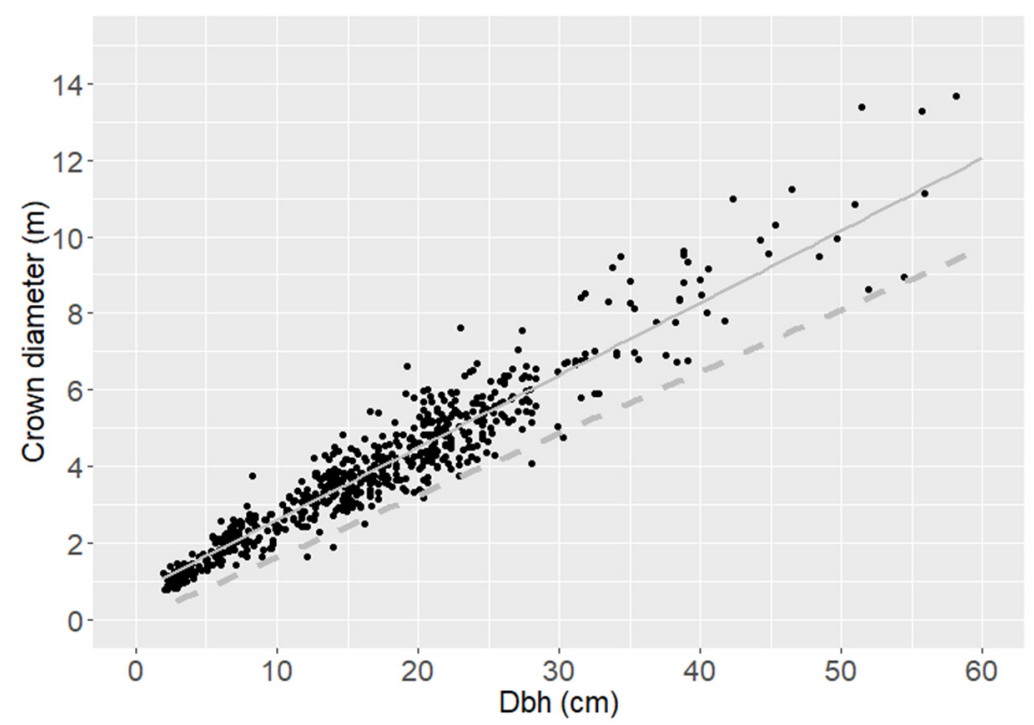

Figure 4. Scatterplot between tree $\mathrm{dbh}$ and crown diameter. The modeled relationship is shown by the solid gray line (Equation (1)). The relationships fitted by Hemery et al. [38] is shown by the dashed gray line. 
Table 3. Parameters of the mixed-effects crown model.

\begin{tabular}{ccccc}
\hline & Degree of Freedom & \multicolumn{6}{c}{$\mathbf{6 1 5}$} & \\
\hline & & Estimate & Std Error/Std Dev & $p$-Value \\
\hline \multirow{2}{*}{ Fixed effects } & $\beta_{0}$ & 0.761 & 0.110 & $<0.001$ \\
& $\beta_{1}$ & 0.186 & 0.00409 & $<0.001$ \\
\hline Random plot & $\alpha$ & & 0.320 & \\
effects & $\varepsilon$ & & 0.0856 & \\
\hline
\end{tabular}

\subsection{The Effect of Crown-Release Earliness on Dbh}

As expected, dbh increment was found to depend on silvicultural treatment (Figures 5-7 and Table 4).

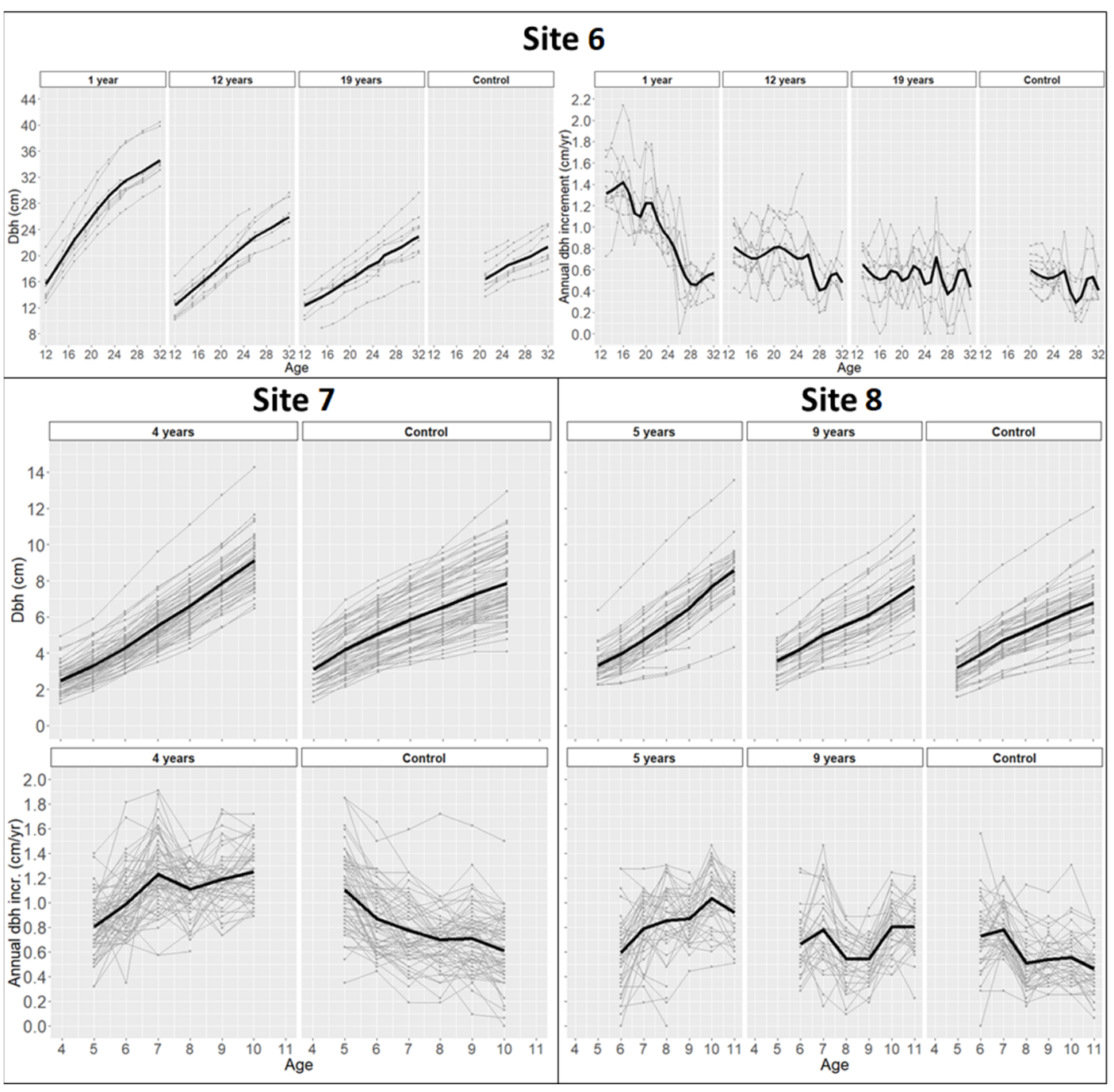

Figure 5. Evolution of $\mathrm{dbh}(\mathrm{cm})$ and dbh increment (cm/year) with tree age for each silvicultural treatment of sites 6, 7 and 8 . 


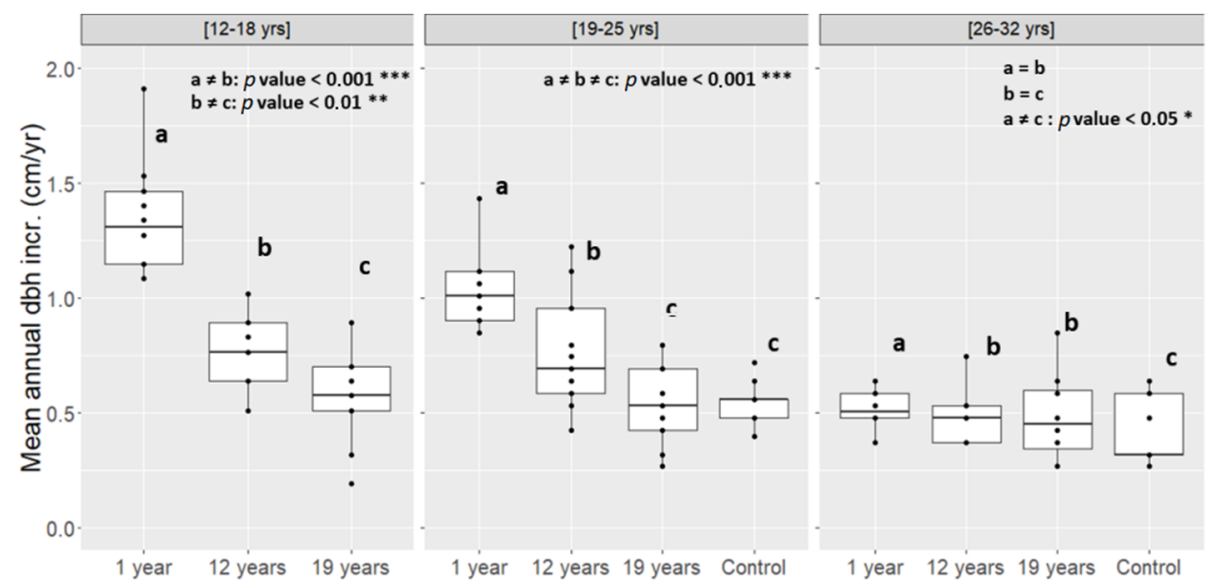

Figure 6. Boxplot of the mean annual dbh increment during age intervals 12-18, 19-25, and 2632 years in site 6 . Significant differences were tested with a Tukey test. Significantly different groups are denoted with different letters.

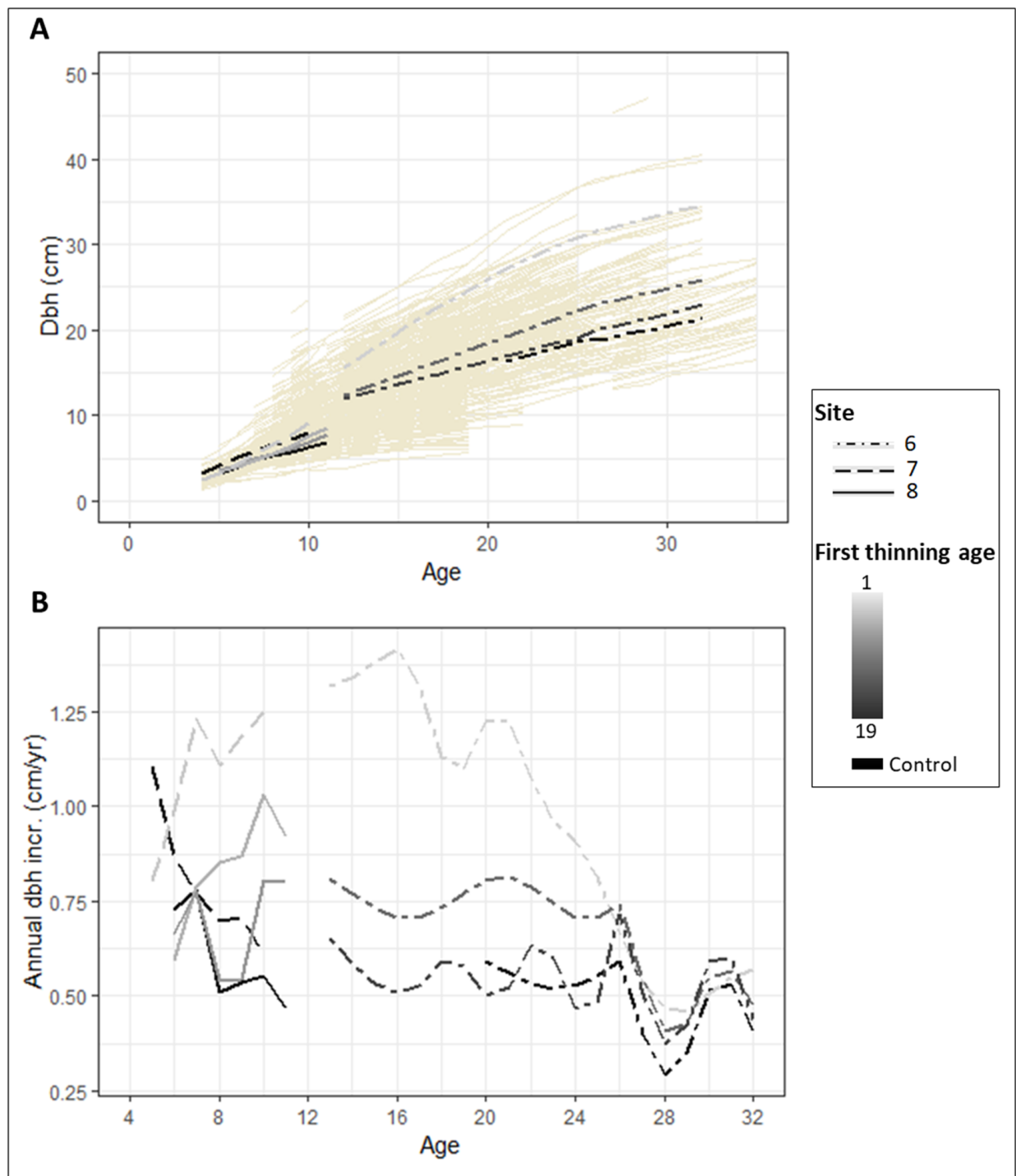

Figure 7. Variation in dbh and dbh growth in sites 6, 7 and 8 across treatments. (A) shows the mean growth curves by site and treatment (thicker lines) superimposed on the growth curve of all the sampled individuals up to 35 years (from Figure 3). (B) shows variation in mean dbh increment in time by site and treatment. 
Table 4. Variation of the mean dbh increment across sites, treatments and monitoring years. $p$-value levels of the ANOVA and Tukey tests are indicated next to the mean values ${ }^{* * *}: p$-value $<0.001, *: 0.01<p$-value $<0.05$, n.s. (nonsignificant): $p$-value $>0.05)$. Significantly different groups are noted with letters.

\begin{tabular}{|c|c|c|c|c|c|c|c|c|c|c|c|c|c|c|c|}
\hline \multirow{2}{*}{\multicolumn{2}{|c|}{$\begin{array}{l}\text { Mean dbh Increment (cm) } \\
\text { and Differences between } \\
\text { Treatments (Letters) }\end{array}$}} & \multicolumn{14}{|c|}{ Age } \\
\hline & & 5 & & 6 & & 7 & & 8 & & 9 & & 10 & & & 11 \\
\hline \multirow{2}{*}{ Site 7} & 4-year & $0.81 \mathrm{a}$ & \multirow{2}{*}{ n.s } & $0.99 \mathrm{a}$ & \multirow{2}{*}{ n.s } & $1.23 \mathrm{a}$ & \multirow{2}{*}{$* * *$} & $1.11 \mathrm{a}$ & \multirow{2}{*}{$* * *$} & $1.19 \mathrm{a}$ & \multirow{2}{*}{$* * *$} & $1.25 \mathrm{a}$ & \multirow{2}{*}{$* * *$} & & \\
\hline & Control & $1.11 \mathrm{a}$ & & $0.87 \mathrm{a}$ & & $0.77 \mathrm{~b}$ & & $0.70 \mathrm{~b}$ & & $0.71 \mathrm{~b}$ & & $0.61 \mathrm{~b}$ & & & \\
\hline \multirow{3}{*}{ Site 8} & 5-year & & & $0.60 \mathrm{a}$ & \multirow{3}{*}{ n.s. } & $0.80 \mathrm{a}$ & \multirow{3}{*}{ n.s. } & 0.85 a & \multirow{3}{*}{$* * *$} & $0.87 \mathrm{a}$ & \multirow{3}{*}{$* * *$} & $1.03 \mathrm{a}$ & \multirow{3}{*}{$* * *$} & $0.92 \mathrm{a}$ & \multirow{3}{*}{$\begin{array}{c}a-c, b-c:{ }^{* * *} \\
a, b:{ }^{*}\end{array}$} \\
\hline & 9-year & & & $0.66 \mathrm{a}$ & & $0.78 \mathrm{a}$ & & $0.54 \mathrm{~b}$ & & $0.54 \mathrm{~b}$ & & $0.80 \mathrm{~b}$ & & $0.80 \mathrm{~b}$ & \\
\hline & Control & & & $0.73 \mathrm{a}$ & & $0.78 \mathrm{a}$ & & $0.51 \mathrm{~b}$ & & $0.54 \mathrm{~b}$ & & $0.55 \mathrm{c}$ & & $0.47 \mathrm{c}$ & \\
\hline
\end{tabular}

In site 6, four treatments were applied: control, 1-year, 12-year and 19-year treatment according to the age of the first crown release. We observed that the earlier the first crown release, the larger was the mean $\mathrm{dbh}$ at the end of the monitoring period once the trees were 32 years old (Figure 5). At age 32 years, the average dbh of the target trees released when they were 1 year old was $34.6 \mathrm{~cm}( \pm 3.1 \mathrm{~cm}$ standard deviation). Two out of the 10 birch even reached $40 \mathrm{~cm}$ in $\mathrm{dbh}$. By contrast, in the 19-year treatment, the mean dbh was only about $22.9 \mathrm{~cm}( \pm 4.1 \mathrm{~cm})$ at 32 years old. At age 32 years, the average dbh was $7 \%, 21 \%$ and $62 \%$ greater than that of the control treatment for the 19-, 12- and 1-year treatment respectively. The mean dbh increments of the birches released at age 1 year was $1.3 \mathrm{~cm} /$ year $( \pm 0.7 \mathrm{~cm} /$ year) from 12 to 21 years. In the other silvicultural treatments, it ranged between 0.5 and $0.8 \mathrm{~cm}$ /year during this period. Birch released at age 12 years seemed to have gained little from the crown release. We did not observe any significant, sudden increase in the dbh increment of these trees but they did show a slightly greater mean dbh increment than those of the 19-year or the control treatment (Figure 5). Birch released at age 19 years seemed to have gained very little from late crown release, their $\mathrm{dbh}$ increment being comparable to that in the control treatment.

The differences between the mean dbh increments across treatments seemed to level off over time (Figures 5-7). The mean dbh increment was statistically significant across treatments considering a first period when the trees were 12-18 years old. During a second period when the trees were 19-25 years old, the dbh increment was statistically different across all the treatments except between the control and the 19-year treatments. Considering a last period, when the trees were 26-32 years old, the treatments showed quite similar increments but the trees in the 1-year treatment showed a slightly higher and significant $\mathrm{dbh}$ increment than those in the control treatment.

In site 7, two treatments were applied: the control and the 4-year treatment according to the age of the first crown release. The dbh of the target trees increased for 2 years after crown release and then stabilized at a value of about $1.2 \mathrm{~cm} /$ year $( \pm 0.2 \mathrm{~cm} /$ year) (Figure 5 and Table 4). In the control treatment, the mean $\mathrm{dbh}$ increments decreased continuously during the 6 years of monitoring. At the end of the monitoring period, when the trees were 10 years old, their mean dbh increment was half $(0.6 \mathrm{~cm} /$ year \pm 0.3$)$ that of the trees that were previously crown-released (Table 4).

In site 8, three treatments were applied: control, 5-year and 9-year, according to the age of the first crown release. When the trees were 6 and 7 years old, no statistical difference was found across treatments and dbh increment ranged between 0.6 and $0.8 \mathrm{~cm} /$ year (Table 4). Statistical differences were found once the trees were 8 years old. From age 8 9 years, the mean dbh increment of the trees released at age 5 years was about $0.9 \mathrm{~cm} /$ year $( \pm 0.2 \mathrm{~cm} /$ year $)$ whereas it was about $0.5 \mathrm{~cm} /$ year $( \pm 0.2 \mathrm{~cm} /$ year $)$ in the other two treatments where no crown release had been carried out at that time (Figure 5 and Table 4). When the trees were older than 10 years, the dbh increment was significantly different in all treatments. Following the first crown release, mean dbh increment increased in the 9-year treatment and reached $0.8 \mathrm{~cm} /$ year $( \pm 0.2 \mathrm{~cm} /$ year $)$ at age 10 years. The highest dbh 
increment was found in the 5-year treatment $(1.0 \pm 0.2 \mathrm{~cm} /$ year $)$. The lowest was found in the control treatment $(0.6 \pm 0.2 \mathrm{~cm} /$ year) (Figure 5 and Table 4$)$.

\section{Discussion}

\subsection{Limits of the Sample}

To address our research questions, we built an original data set gathering information from different in situ experiments. This approach had some disadvantages. In particular, the number of observations was not well-balanced across sites, tree ages and treatments (Table 1 and Figure 3). It can be assumed that the between- and within-stand density variability before the first crown release influenced individual $\mathrm{dbh} /$ age ratio, and thereby the impact of the competition at a given age. We could therefore not use "age of first crown release" to distinguish the between-plot treatments as would have been appropriate in systematic plantations. Consequently, some analyses were carried out site by site. Also, for the most recent monitored trees and particularly for the younger trees, past competition history was well-known and crown release had been carried out earlier and more intensely, whereas for some other trees, particularly for the older ones, the past competition was not always known. Most of the trees that had been monitored for a longer period of time had likely experienced very different growing conditions, such as age (Table 1) and intensity of the first crown release, from those experienced by the last monitored trees. At this time, even if crown release started earlier and was stronger than for all the other common tree species, there was no knowledge of the real needs of birch species $[9,26]$. Our study shows that the impact of late thinning on dbh growth in birch pure natural regeneration is quite low (Figures 5 and 6 and Table 4).

\subsection{Crown Development of Target Trees}

Crown diameter is one of the determining factors of dbh growth, linked to the photosynthetic capacity of a tree [39]. We found a strong linear relationship between $\mathrm{dbh}$ and crown diameter (Figure 4) as already reported for some shade-intolerant pioneer species $[23,38]$. Our model forecasts a larger crown diameter for a given dbh with a slightly higher slope than the model of $[23,38]$ (Figure 4), established on naturally growing birch in forests in England, Scotland and Poland. This is probably because our sample focuses on crown-released target birch, consistent with the observations of Hein et al. [9]. Our model of crown development is therefore designed for birch under crop tree silviculture and can be used for managing the crown space needed for optimal crown development in western European conditions. For example, if the goal is to produce 40,50 and $60 \mathrm{~cm}$ dbh trunks, crown diameter at the end of the rotation, and thus the distance required between target birch, is around 8, 10 and $12 \mathrm{~m}$, respectively (Figure 4).

\subsection{Diameter at Breast Height Growth According to Age of First Crown Release}

Tree competition can rapidly alter the dbh growth of naturally regenerated birch. Our results confirmed the findings of Prévosto et al. [21,22] and Lemaire [17]. Without silvicultural intervention, the dbh growth can be reduced as early as age 4-7 years. We particularly evidenced this effect on birch aged 4-5 years in sites 7 and 8 (Figure 5 and Table 4). In these sites, between ages 4 and 10 years, mean $\mathrm{dbh}$ of the earliest crown released target trees grew on average $40 \%$ faster than those in the controls. At age 10 years, average $\mathrm{dbh}$ of the crown-released trees was about $1 \mathrm{~cm}$ greater than that of the controls. When the first crown release occurred a few years later, at age 9 years instead of 5 in site 8 , target trees did not completely recover their dbh growth level in the following two years (Figure 5 and Table 4) and may keep a lower growth level thereafter.

Besides spurring the very early growth of target trees, early crown thinning may also have long-lasting effects [23]. Between ages 12 and 24 years, the highest dbh increments were always observed for the trees that were released the earliest in site 6 . At age 26 years, the trees that were released very early (from 1 years of age) were on average $9 \mathrm{~cm}$ larger than those released later, from age 12 years. The difference from the 19 -year and the control 
treatments were $11 \mathrm{~cm}$ and $13 \mathrm{~cm}$, respectively. There was thus no great gain between these last three treatments. Early crown release is therefore a way to reduce forest rotation $[19,20]$ and thereby ensure that large logs are produced before wood depreciation occurs.

\subsection{Timber Production Objective}

In the ecological conditions studied, our results highlighted that trunks around $50 \mathrm{~cm}$ in dbh could be produced in less than 60 years, which is considered as the maximum harvest age, as older trees are too prone to wood rot and discoloration $[8,9,27]$. This statement is a graphical interpretation (Figure 3) mainly based on the nine trees meeting these two criteria simultaneously in our dataset. Very few large-sized birches and birches older than 40 years were measured. Moreover, we can assume that most of the target trees older than 20 years probably did not receive a sufficiently dynamic treatment, in line with the negative consequences of competition on diameter growth, as discussed above. It can thus be considered that this objective is not overambitious. With appropriate crown releases, the objective of $60 \mathrm{~cm}$ dbh logs proposed by Hein et al. [9], Wilhelm and Rieger [26], Vanhellemont et al. [13] or in HOMBURG1 [40] seems realistic. Following market studies $[9,10,26]$ and high-value birch log sales in Saarland [40], this size seems to correspond to the maximum target $\mathrm{dbh}$ for high-value silver birch logs. Alternatively, harvestable commercial birches of $40 \mathrm{~cm}$ dbh could be produced in less than 40 years.

\subsection{Silvicultural Implications}

Our study confirms that it is possible to produce high-value birch trunks with a dbh of $50 \mathrm{~cm}$ within a forest rotation of about 50-60 years. Furthermore, the size of trees, even for birch, and even for a short term in managed forests, plays an important role in the diversity of species that depend on it [41]. Having such large logs rapidly in comparison with more shade-tolerant species is beneficial not only from an economic, but also from an ecological point of view. After this age, the risk of wood coloration and rot becomes high. Applying a crop tree silviculture with early crown release appears to be a good way to achieve this goal. Given the crown diameter of 50-year-old birch (Equation (1), Figure 4), forest managers can select about 100 target trees/ha. From a diameter growth point of view, crown release should start very soon after the canopy closes, i.e., as early as 4-5 years in ordinary dense pure birch natural regeneration, to avoid any likely persistent reduction in $\mathrm{dbh}$ growth of the target trees. This is most important for birch silviculture unlike some other species such as oak (Quercus sp.) or beech (Fagus sylvatica L.) e.g., [26] and even for other fast-growing species such as maple (Acer pseudoplatanus) or black alder (Alnus glutinosa) [42]. Moreover, determining the optimal age of the first crown release depends on several factors including initial stand density, growth rate in relation with site conditions, desired log size and quality $[6,28]$, and the cost of the early crown releases and associated pruning.

\section{Conclusions}

In the western European forestry context, silver birch, which naturally regenerates profusely, is a potentially useful resource to face ongoing changes. Our analysis of the dbh growth of 814 target silver birch trees in 38 naturally regenerated stands confirms that large-sized, high-value logs can be produced.

However, achieving this goal requires a specific silvicultural treatment adapted to the growth pattern and the sensitivity to crown competition of birch. Logs must be produced rapidly to limit the risk of wood coloration and rot, which appears as early as age 60 years. Birch needs dynamic silviculture to gain from its high but unsustainable early growth potential and to limit the rotation period.

In the context of dense natural regenerations (e.g., after clearcut), our findings are that crop tree silviculture with very early crown release, from age 4-7 years, is the key to producing large marketable trunks. Based on crown development of target trees, we also provide first guidelines for the spacing between target trees. 
As the interest of foresters in birch is growing but still recent, our study was limited by data availability. Further studies are needed to accumulate data in birch stands managed with crop tree silviculture and early crown release. A dbh growth model could then be fitted, including other parameters such as height crown proportion and base of the living crown, soil condition effects and a thorough cost-benefit analysis.

Author Contributions: Conceptualization, H.D. and H.C.; Data curation, H.D.; Formal analysis, H.D. and G.L.; Funding acquisition, H.C.; Investigation, H.D.; Methodology, H.D. and H.C.; Project administration, H.D.; Resources, H.D.; Software, G.L.; Validation, G.L.; Visualization, H.D., H.C. and G.L.; Writing—original draft, H.D.; Writing—review \& editing, H.C. and G.L. All authors have read and agreed to the published version of the manuscript.

Funding: This work was supported by the Walloon Region of Belgium (Service Public de Wallonie) through the "Accord-Cadre de Recherche et Vulgarisation Forestières" project.

Data Availability Statement: The data presented in this study are available on request from the corresponding author.

Acknowledgments: We warmly thank the technical team who helped make the measurements and carry out the tree cutting, and the forest managers and owners who shared their experience and authorized us to take measurements in their birch stands. Special thanks are due to José Layon for precious volunteer help in the design of the experiments on site 6,7 and 8 and for all measurements and tree cutting. We thank Richard Ryan for English language editing. We thank anonymous reviewers for their constructive feedback.

Conflicts of Interest: The authors declare no conflict of interest.

\section{References}

1. Lindner, M.; Maroschek, M.; Netherer, S.; Kremer, A.; Barbati, A.; Garcia-Gonzalo, J.; Seidl, R.; Delzon, S.; Corona, P.; Kolström, M.; et al. Climate change impacts, adaptive capacity, and vulnerability of European forest ecosystems. For. Ecol. Manag. 2010, 259, 698-709. [CrossRef]

2. Brang, P.; Spathelf, P.; Larsen, J.B.; Bauhus, J.; Boncına, A.; Chauvin, C.; Drössler, L.; Garcra-Güemes, C.; Heiri, C.; Kerr, G.; et al. Suitability of close-to-nature silviculture for adapting temperate European forests to climate change. Forestry 2014, 87, 492-503. [CrossRef]

3. Jucker, T.; Bouriaud, O.; Avăcăriei, D.; Coomes, D.A. Stabilizing effects of diversity on aboveground wood production in forest ecosystems: Linking patterns and processes. Ecol. Lett. 2014, 17, 1560-1569. [CrossRef] [PubMed]

4. Messier, C.; Bauhus, J.; Doyon, F.; Maure, F.; Sousa-Silva, R.; Nolet, P.; Mina, M.; Aquilué, N.; Fortin, M.-J.; Puettmann, K. The functional complex network approach to foster forest resilience to global changes. Forest Ecosyst. 2019, 16. [CrossRef]

5. Dubois, H.; Latte, N.; Lecomte, H.; Claessens, H. Le bouleau, une essence qui s'impose. Description de la ressource dans son aire de distribution. For. Nat. 2016, 140, 44-58. (In French)

6. Dubois, H.; Verkasalo, E.; Claessens, H. Potential of Birch (Betula pendula Roth and B. pubescens Ehrh.) for Forestry and Forestbased Industry Sector within the Changing Climatic and Socio-economic Context of Western Europe. Forests 2020, 11, 336. [CrossRef]

7. Perala, D.A.; Alm, A.A. Reproductive ecology of birch: A review. For. Ecol. Manag. 1990, 32, 1-38. [CrossRef]

8. Niemistö, P.; Viherä-Aarnio, A.; Velling, P.; Heräjärvi, H.; Verkasalo, E. Koivun Kasvatus ja Käyttö. [Silviculture and Use of Birch]; Finnish Forest Research Institute and Metsäkustannus Ltd.: Metsäntutkimuslaitos ja Metsäkustannus, Finland, 2008 ; p. 254. (In Finnish)

9. Hein, S.; Winterhalter, D.; Wilhelm, G.J.; Kohnle, U. Wertholzproduktion mit der Sandbirke (Betula pendula Roth): Waldbauliche Moglichkeiten und Grenzen. Allg. For. Jagdztg. 2009, 180, 206-219. (In German)

10. Hynynen, J.; Niemistö, P.; Viherä-Aarnio, A.; Brunner, A.; Hein, S.; Velling, P. Silviculture of birch (Betula pendula Roth and Betula pubescens Ehrh.) in northern Europe. Forestry 2010, 83, 103-119. [CrossRef]

11. Kleinschmit, A. The Broadeaf Citizen-Broadening the innovatice use of European hardwoods. In Proceedings of the 6th International Scientific Conference on Hardwood Processing, Lahti, Finland, 25-28 September 2017; Möttönen, V., Heinonen, E., Eds.; Natural Resources Institute Finland: Helsinki, Finland, 2017; pp. 14-15.

12. Teischinger, A. From Forest to Wood Production-A selection of challenges and opportunities for innovative hardwood utilization. In Proceedings of the 6th International Scientific Conference on Hardwood Processing, Lahti, Finland, 25-28 September 2017; Möttönen, V., Heinonen, E., Eds.; Natural Resources Institute Finland: Helsinki, Finland, 2017; p. 13.

13. Vanhellemont, M.; Van Acker, J.; Verheyen, K. Exploring life growth patterns in birch (Betula pendula). Scand. J. For. Res. 2016, 31, 7. [CrossRef] 
14. Frauendorfer, R. Forstliche Hilfstafeln Schriftenreihe der forstlichen Bundes-Versuchsans-talt Mariabrunn Band II; Kommissionsverlag der Österreichischen Staatsdruckerei: Wien, Austria, 1954; p. 168. (In German)

15. Eriksson, H.; Johansson, U.; Kiviste, A. A site-index model for pure and mixed stands of Betula pendula and Betula pubescens in Sweden. Scand. J. For. Res. 1997, 12, 149-156. [CrossRef]

16. Diéguez-Aranda, U.; Grandas-Arias, J.A.; Álvarez-González, J.G.; Gadow, K.v. Site quality curves for birch stands in north-western Spain. Silva Fenn. 2006, 40, 631-644. [CrossRef]

17. Lemaire, J. Contribution à l'étude de la sylviculture du Betula pendula Roth. La sylviculture du Betulla pendula Roth au Bois de Lauzelle (Louvain-la-Neuve). Master's Thesis, Université Catholique de Louvain, Louvain-la-Neuve, Belgium, 1998 ; p. 175. (In French)

18. Zâlîtis, T.; Zâlîtis, P. Growth of Young Stands of Silver Birch (Betula pendula Roth.) Depending on Pre-Commercial Thinning Intensity. Baltic Forestry 2007, 13, 61-67.

19. Rytter, L.; Werner, M. Influence of early thinning in broadleaved stands on development of remaining stems. Scand. J. For. Res. 2007, 22, 198-210. [CrossRef]

20. Rytter, L. Growth dynamics of hardwood stands during the precommercial thinning phase-Recovery of retained stems after competition release. For. Ecol. Manag. 2013, 302, 264-272. [CrossRef]

21. Prévosto, B.; Agrech, G. Dynamique et typologie des accrus. Le cas des bétulaies dans la chaîne des. Puys. Rev. For. Fr. 1998, 50, 46-58. (In French)

22. Prévosto, B.; Coquillard, P.; Gueugnot, J. Growth models of silver birch (Betula pendula Roth.) on two volcanic mountains in the French Massif Central. Plant Ecol. 1999, 144, 231-242. [CrossRef]

23. Cameron, A.D. Managing birch woodlands for the production of quality timber. Forestry 1996, 69, 357-371. [CrossRef]

24. de Champs, J. Mesures sylvicoles préventives. Rev. For. Fr. 1987, 39, 313-322. (In French) [CrossRef]

25. Verkasalo, E. Hieskoivun laatu vaneripuuna. Abstract: Quality of White Birch (Betula pubescens Ehrh.) for Veneer and Plywood. Dissertation for D.For. in wood science and forest products. Department of Logging and Utilization of Forest Resources, University of Helsinki, Finland. Finn. For. Res. Inst. Res. Pap. 1997, 632, 483. (In Finnish)

26. Wilhelm, G.J.; Rieger, H. Naturnahe Waldwirtschaft-Mit der QD-Strategie: Eine Strategie für Den Qualitätsgeleiteten und Schonenden Gebrauch des Waldes Unter Achtung der Gesamten Lebewelt; Eugen Ulme KG: Stuttgart, Germany, 2013; p. 207. (In German)

27. Luostarinen, K.; Verkasalo, E. Birch as Sawn Timber and in Mechanical Further Processing in Finland. A Literature Study. Silva Fenn. Monogr. 2000, 1, 40.

28. Niemistö, P.; Kilpeläinen, H.; Heräjärvi, H. Effect of pruning season and tool on knot occlusion and stem discolouration in Betula pendula-Situation five years after pruning. Silva Fenn. 2019, 53, 29. [CrossRef]

29. Cameron, A.D.; Dunham, R.A.; Petty, J.A. The effects of heavy thinning on stem quality and timber properties of silver birch (Betula pendula Roth). Forestry 1995, 68, 275-285. [CrossRef]

30. Gómez-García, E.; Crecente-Campo, F.; Tobin, B.; Hawkins, M.; Nieuwenhuis, M.; Dieguez-Aranda, U. A dynamic volume and biomass growth model system for even-aged downy birch stands in south-western Europe. Forestry 2014, 87, 165-176. [CrossRef]

31. Petit, S.; Claessens, H.; Vincke, C.; Ponette, Q.; Marchal, D. Le Fichier écologique des essences, version 2.0. For. Nat 2017, 143, 12-19. (In French)

32. Wood, J.E.; Von Althen, F.W.; Mitchell, E.G. Crown release improves growth of 20-year-old Betula alleghaniensis in tolerant northern hardwood stands. New For. 1996, 12, 87-99. [CrossRef]

33. Meng, S.X.; Rudnicki, M.; Lieffers, V.J.; Reid, D.B.; Silins, U. Preventing crown collisions increases the crown cover and leaf area of maturing lodgepole pine. J. Ecol. 2006, 94, 681-686. [CrossRef]

34. R Core Team. R: A Language and Environment for Statistical Computing; R Foundation for Statistical Computing: Vienna, Austria, 2017; Available online: https: / / www.R-project.org/ (accessed on 25 March 2021).

35. Wickham, H.; François, R.; Henry, L.; Müller, K. dplyr: A Grammar of Data Manipulation. R Package Version 0.8.0.1. 2019. Available online: https:/ /CRAN.R-project.org/package=dplyr (accessed on 25 March 2021).

36. Pinheiro, J.; Bates, D.; DebRoy, S.; Sarkar, D.; R Core Team. nlme: Linear and Nonlinear Mixed Effects Models. R Package Version 3.1-131. 2017. Available online: https: / /CRAN.R-project.org/package=nlme (accessed on 25 March 2021).

37. Wickham, H. ggplot2: Elegant Graphics for Data Analysis, 2nd ed.; Springer: New York, NY, USA, 2016; p. 260.

38. Hemery, G.E.; Savill, P.S.; Pryor, S.N. Applications of the crown diameter-stem diameter relationship for different species of broadleaved trees. For. Ecol. Manag. 2005, 215, 285-294. [CrossRef]

39. Cole, W.G.; Lorimer, C.G. Predicting tree growth from crown variables in managed northern hardwood stands. For. Ecol. Manag. 1994, 67, 159-175. [CrossRef]

40. HOMBURG1. Wertholzperspektiven im Biosphärenwald, HOMBURG1, Homburg, Germany; Press Article 13 May 2016. Available online: http:/ / homburg1.de/wertholzperspektiven-im-biosphaerenwald-10909/ (accessed on 25 March 2021). (In German).

41. Paillet, Y.; Debaive, N.; Archaux, F.; Cateau, E.; Gilg, O.; Guilbert, E. Nothing else matters? Tree diameter and living status have more effects than biogeoclimatic context on microhabitat number and occurrence: An analysis in French forest reserves. PLoS ONE 2019, 14, e216500. [CrossRef]

42. Claessens, H.; Oosterbaan, A.; Savill, P.; Rondeux, J. A review of the characteristics of black alder (Alnus glutinosa (L.) Gaertn.) and their implications for silvicultural practices. Forestry 2010, 83, 163-175. [CrossRef] 